\title{
Population Studies and Carrageenan Properties in Eight Gigartinales (Rhodophyta) from Western Coast of Portugal
}

\author{
Leonel Pereira \\ Institute of Marine Research (IMAR-CMA), Department of Life Sciences, Faculty of Sciences and Technology, University of Coimbra, \\ 3001-455 Coimbra, Portugal
}

Correspondence should be addressed to Leonel Pereira; leonel@bot.uc.pt

Received 26 August 2013; Accepted 13 September 2013

Academic Editors: M. Cledon, G.-C. Fang, and R. Moreira

Copyright (C) 2013 Leonel Pereira. This is an open access article distributed under the Creative Commons Attribution License, which permits unrestricted use, distribution, and reproduction in any medium, provided the original work is properly cited.

Eight carrageenophytes, representing seven genera and three families of Gigartinales (Florideophyceae), were studied for 15 months. The reproductive status, dry weight, and carrageenan content have been followed by a monthly random sampling. The highest carrageenan yields were found in Chondracanthus acicularis (61.1\%), Gigartina pistillata (59.7\%), and Chondracanthus teedei var. lusitanicus (58.0\%). Species of Cystocloniaceae family produces predominantly iota-carrageenans; Gigartinaceae family produces hybrid kappa-iota carrageenans (gametophytic plants) and lambda-family carrageenans (sporophytic plants); Phyllophoraceae family produces kappa-iota-hybrid carrageenans. Quadrate destructive sampling method was used to determine the biomass and line transect. Quadrate nondestructive sampling method, applied along a perpendicular transect to the shoreline, was used to calculate the carrageenophytes cover in two periods: autumn/winter and spring/summer. The highest cover and biomass were found in Chondrus crispus $\left(3.75 \%-570 \mathrm{~g} / \mathrm{m}^{2}\right)$, Chondracanthus acicularis $\left(3.45 \%-99 \mathrm{~g} / \mathrm{m}^{2}\right)$, Chondracanthus teedei var. lusitanicus $\left(2.45 \%-207.5 \mathrm{~g} / \mathrm{m}^{2}\right)$, and Mastocarpus stellatus $\left(2.02 \%-520 \mathrm{~g} / \mathrm{m}^{2}\right)$.

\section{Introduction}

Carrageenans are industrially important hydrocolloids that are found in various red seaweeds (Gigartinales, Rhodophyta) $[1,2]$. Carrageenans are a family of water soluble, linear, and sulfated galactans. They are composed of alternating 3 -linked $\beta$-D-galactopyranose (G-units) and 4-linked $\alpha$-D-galactopyranose (D-units) or 4-linked 3,6-anhydro$\alpha$-D-galactopyranose (DA-units), forming the disaccharide repeating unit of carrageenans. The most common types of carrageenans are traditionally identified by a Greek prefix and more recently by the letter codes developed by Knutsen and collaborators [3]. The three commercially most important carrageenans are called iota-, kappa-, and lambdacarrageenan. The letter codes of these carrageenan types are G4S-DA, G4S-DA2S, and G2S-D2S,6S, respectively. Kappacarrageenan is present, over all, in the species pertaining to the Hypneae (Hypnaceae) and Kappaphycus genera (Solieriaceae) and the species belonging to the Eucheuma genus (Solieriaceae), are the principal source of iota-carrageenan [4-6]. Kappa/iota-hybrid carrageenans are found in the gametophytic life phases of several species in the families of Gigartinaceae and Phyllophoraceae [7-9]. The mu- and nucarrageenan, existing in the native phycocolloid samples, are the biologic precursors of kappa- and iota-carrageenan [10]. In vivo, iota- and kappa-carrageenan are formed enzymatically from the precursor carrageenans by a sulfohydrolase $[11,12]$. In vitro, these precursor residues are converted to the corresponding gelling carrageenan on treatment with alkali. Alkali extraction is commonly used in the commercial production of kappa- and iota-carrageenan to increase the 3,6-anhydro-D-galactose content, since this results in a product with enhanced gelling properties $[13,14]$. The tetrasporic life phase of Gigartinaceae contains carrageenans of the lambda family. In general, carrageenan serves as a gelling (kappa-family carrageenans), stabilizing, and viscosity-building agent (lambda-family carrageenans) in food products, pharmaceutical formulations, cosmetics, and oil well drilling fluid $[2,15]$.

The species Chondrus crispus and Mastocarpus stellatus were the first seaweed used for carrageenan extraction. Due to the fact that both species live in the same biotype, their 
harvest is generally simultaneous. Although C. crispus may occur in considerable quantities to a depth of $12 \mathrm{~m}$ in the sublittoral zone of the maritime provinces of Canada, in Europe, it is found mainly in intertidal rock pools $[16,17] . M$. stellatus is also found in rock pools, mostly in the intertidal zone [16]. In the Northeast Atlantic, both species are found from North Cape (Norway) to Mauritania [17].

Generally, the harvest is made during a period depending on the local customs, climate, and sea behaviour. In Portugal, C. crispus and M. stellatus have been exploited, especially in the north (Minho, Douro, and Beira Litoral) [18-20]. The carrageenophytes are plucked from the intertidal zone during summer, sun dried, sold to concentrators, and then exported $[19,20]$. The collection is controlled by regulations, which first date from 1909, that specify periods of seaweeds harvesting from July to November and require the issuing of licences for each area of the coastline and control prices $[16,19]$.

Population studies and carrageenan content have recently been performed on wild populations of Chondrus crispus and Mastocarpus stellatus, the main species with industrial use and harvested in Galicia (Spain) [21, 22].

In 1955, all the carrageenans were gotten from C. crispus and M. stellatus. Today, these species represent no more than $10 \%$ of the total harvest. Most of the currently used seaweeds in the world are cultivated species belonging to the genera Eucheuma and Kappaphycus as sources of iota- and kappacarrageenan, respectively $[2,9]$.

Large carrageenan processors have fuelled the development of Kappaphycus alvarezii (which goes by the name "cottonii" to the trade) and Eucheuma denticulatum (commonly referred to as "spinosum" in the trade), farming in several countries including the Philippines, Indonesia, Malaysia, Tanzania, Kiribati, Fiji, Kenya, and Madagascar [23]. Indonesia has recently overtaken the Philippines as the world's largest producer of dried carrageenophyte biomass [15].

Shortages of carrageenan-producing seaweeds suddenly appeared in mid-2007, resulting in doubling of the price of carrageenan; some of this price increase was due to increased fuel costs and a weak US dollar (most seaweed polysaccharides are traded in US dollars). The reasons for shortages of the raw materials for processing are less certain; perhaps it is a combination of environmental factors. The drop in production could be also due to a depletion of natural resource caused by a degradation of the habitat and the overexploitation. Most hydrocolloids are experiencing severe price movements. The average prices of carrageenans were US\$10.5/ kg ${ }^{-1}$, and the global sales in 2009 were US\$ 527 million $[9,15,24]$.

The present study was carried out in order to evaluate the population and phycocolloid ecology of several underutilized Gigartinales: Chondracanthus teedei var. lusitanicus (Rodrigues) Bárbara et Cremades (Gigartinaceae), Chondracanthus acicularis (Roth) Fredericq (Gigartinaceae), Gigartina pistillata (S.G. Gmelin) Stackhouse (Gigartinaceae), Calliblepharis jubata (Goodenough et Woodward) Kützing (Cystocloniaceae), Gymnogongrus crenulatus (Turner) J. Agardh (Phyllophoraceae), and Ahnfeltiopsis devoniensis (Greville) P.C. Silva et DeCew (Phyllophoraceae) and to compare them with the traditionally harvested carrageenophytes Chondrus crispus Stackhouse (Gigartina ceae) and Mastocarpus stellatus (Stackhouse) Guiry (Phyllophoraceae). To achieve this goal, a natural population of mixed carrageenophytes situated at Buarcos bay (central north of the Portuguese Atlantic coast) was studied during 15 months. To determine the nature of the produced phycocolloid, we examined and quantified the native and alkali-modified carrageenan extracted from the different phases of life history of the studied carrageenophytes (tetrasporophyte, female gametophyte, and nonfructified thalli) with FTIR-ATR, FT-Raman, and ${ }^{1} \mathrm{H}-\mathrm{NMR}$. The nature of the polysaccharides (without any type of extraction) present in these seaweeds was determined with FTIR-ATR and FT-Raman analysis of the dry ground seaweed $[8,25,26]$.

\section{Material and Methods}

A representative population of the eight studied carrageenophytes, localised at Buarcos bay $\left(40^{\circ} 10^{\prime} 5.99^{\prime \prime} \mathrm{N}\right.$, $\left.8^{\circ} 53^{\prime} 22.27^{\prime \prime} \mathrm{W}\right)$ in the Northern Portuguese coast, was investigated for about 15 months. The plants were collected from a rocky-shore substrate, with numerous sand basins, in the intertidal zone. At each sampling time, $\mathrm{pH}$, salinity, surface water, and air temperature were recorded.

Carrageenophytes coverage was estimated in two periods (autumn/winter and spring/summer), using a modification of the "Braun-Blanquet" scale $[27,28]$. A $100 \mathrm{~cm}\left(1 \mathrm{~m}^{2}\right)$ quadrate, applied along a perpendicular transect $(100 \mathrm{~m})$ to the shoreline, was used to evaluate the carrageenophytes cover.

For determination of biomass and thalli length, eight quadrates $(10 \times 10 \mathrm{~cm})$ were randomly positioned in the extensive beds of carrageenophytes and destructively sampled [29-31]. The samples were rinsed in distilled water and dried in ventilated oven to constant weight $\left(60^{\circ} \mathrm{C}\right)$. Biomass was expressed as a dry weight per square meter of substrate.

The percentage of each lifecycle phase, dry weight, and carrageenan content was evaluated. For these determinations, 100 individuals, larger than $3 \mathrm{~cm}$, of each species were collected at random, monthly. At the laboratory, carrageenophytes fronds were sorted into the different lifecycle phases and then rinsed in distilled water to eliminate debris and salt on the thalli surfaces and dried, in a ventilated oven, to constant weight at $60^{\circ} \mathrm{C}$. Carrageenan extraction was carried out according to the process described by Pereira and collaborators $[25,32]$.

Data on plant size, biomass, lifecycle phase, dry weight, and yields were presented as average \pm standard error (with $n=$ number of samples used in the study). One-way ANOVA (considering three values of $P$ : significant, $P<0.05$, very significant, $P<0.01$, and highly significant, $P<0.001$ ) of plant size, biomass, lifecycle phase, dry weight, and carrageenan yields was made to analyzse possible variances between seasons [33].

Samples of ground, dried algal material were analysed by FTIR-ATR and FT-Raman [8, 25, 26, 32] for the determination of native phycocolloid composition. The FTIR-ATR spectra of ground, dried seaweed, native and alkali-modified 
carrageenan were recorded on an IFS 55 spectrometer, using a Golden Gate single-reflection diamond ATR system, with no need for sample preparation. All spectra are the average of two counts, with 128 scans each and a resolution of $2 \mathrm{~cm}^{-1}$. The room-temperature FT-Raman spectra were recorded on a RFS-100 Bruker FT-spectrometer, using a Nd:YAG laser with excitation wavelength of $1064 \mathrm{~nm}$. Each spectrum is the averaging of two repeated measurements of 150 scans each and a resolution of $2 \mathrm{~cm}^{-1}$.

${ }^{1} \mathrm{H}-\mathrm{NMR}$ spectra were taken on a Bruker AMX600 spectrometer operating at $500.13 \mathrm{MHz}$ at $65^{\circ} \mathrm{C}$. Typically, 64 scans were taken with an interpulse delay of $5 \mathrm{~s}\left(T_{1}\right.$ values for the resonance of the anomeric protons of kappaand iota-carrageenan are shorter than $1.5 \mathrm{~s}$ ). Sample preparation for the ${ }^{1} \mathrm{H}$-NMR experiments involved dissolving the carrageenan sample $\left(5 \mathrm{mg} \mathrm{mL}^{-1}\right)$ at $80^{\circ} \mathrm{C}$ in $\mathrm{D}_{2} \mathrm{O}$, containing $1 \mathrm{mM}$ TSP (3-(trimethylsilyl) propionic-2,2,3,3- $d_{4}$ acid sodium salt) and $20 \mathrm{mM} \mathrm{Na} \mathrm{HPO}_{4}$, followed by sonication for $1 \mathrm{~h}$ three times in a sonicator bath (Branson 2510). Chemical shifts $(\delta)$ are referred to the internal TSP standard $(\delta=$ $-0.017 \mathrm{ppm}$ ) relative to the IUPAC recommended standard DSS for ${ }^{1} \mathrm{H}$ according to van de Velde and collaborators [34] and Pereira and van de Velde [1]. Assignments of the ${ }^{1} \mathrm{H}-\mathrm{NMR}$ spectra were based on the chemical shift data summarised by van de Velde and collaborators [14, 34].

\section{Results and Discussion}

Table 1 shows the most significant phycocolloid parameters: harvest season, lifecycle phase, yields, and carrageenan composition. Carrageenophytes cover, dry weight, and carrageenan content are presented in Figures 1 and 2, respectively.

3.1. Physical-Chemical Data. In Buarcos bay, the average water temperature ranged from $12^{\circ} \mathrm{C}$ in autumn/winter to $22^{\circ} \mathrm{C}$ in spring/summer, and the mean air temperature varied from $10^{\circ} \mathrm{C}$ to $23^{\circ} \mathrm{C}$ between these periods. In contrast, the $\mathrm{pH}$ and salinity have not changed significantly between seasons, with average values of 8.3 and $32.8 \mathrm{~S} \%$, respectively.

3.2. Cover Biomass, and Plant Size. C. crispus is the dominant species regarding the coverage (Figure 2) and the available biomass for harvesting. The highest values of biomass $(570 \mathrm{~g} / \mathrm{m} 2)$ and carrageenan content (see Table 1 ) have been registered in spring/summer. The maximum average length was $13.8 \pm 1.2 \mathrm{~cm}(n=100)$ in summer and a minimum of $8.2 \pm 0.5 \mathrm{~cm}(n=100)$ in winter.

Although it is only the fourth seaweed in terms of cover (Figure 2), M. stellatus shows a high biomass $\left(520 \pm 2.0 \mathrm{~g} / \mathrm{m}^{2}\right.$, $n=8)$ in spring/summer. The average length of this species was $6.3 \pm 0.5 \mathrm{~cm}(n=13)$, with a maximum of $9.5 \pm 1.2 \mathrm{~cm}(n=$ $100)$ in summer and a minimum of $4.1 \pm 0.8 \mathrm{~cm}(n=100)$ in winter. The data on seasonal variation length show statistical significance (one-way ANOVA, $P<0.001$ ).

In spite of not being a harvested seaweed, it is surprising that, among the carrageenophytes studied, C. teedei var. lusitanicus is one of those which presents the highest values of average carrageenan yields (Figure 1), cover (Figure 2), and biomass $\left(594 \pm 10.5 \mathrm{~g} / \mathrm{m}^{2}\right)$ in spring/summer. The maximum average length was $7.7 \pm 0.4 \mathrm{~cm}(n=100)$ in summer and a minimum of $2.9 \pm 0.2 \mathrm{~cm}(n=100)$ in winter. The biomass values ranged between $110 \pm 1.9 \mathrm{~g} / \mathrm{m}^{2}(n=8)$ in summer and $594 \pm 10.5 \mathrm{~g} / \mathrm{m}^{2}(n=8)$ in late spring. Biomass and length showed low values in autumn and winter, a small increase occurred in early spring, and the highest values of these parameters were recorded in early summer.

The highest carrageenan yields, in this study, were recorded in G. pistillata, with an average value of the $38.7 \%$ (Figure 1). Nevertheless, the coverage and biomass are relatively low (Figure 2). The second highest coverage was found in C. acicularis (Figure 2), but this carrageenophyte presents a low biomass mainly in spring/summer $\left(22 \pm 0.2 \mathrm{~g} / \mathrm{m}^{2}, n=\right.$ $8)$. This carrageenophyte presents an isomorphic triphasic lifecycle, but the nonfertile thalli and the tetrasporophytes are difficult to distinguish from one another, and consequently these reproductive phases were not separated. Due to the thalli nature, very thin and tangles, the data on plant size were not done. The cover (Figure 2) and biomass are very low in the remaining carrageenophytes: C. jubata, G. crenulatus, and $A$. devoniensis.

3.3. Lifecycle Phase. C. crispus shows an isomorphic triphasic lifecycle [35-37], although in the studied population, the nonfructified thalli were dominant in most samples (see Figure 3), and the percentage varied from 15.4\% (summer) to $66.7 \%$ (winter). The female gametophytes were present in all samples, varying the proportion from $12.5 \%$ (late winter) to $44.5 \%$ (spring). The tetrasporophytes were also present in all samples, with a maximum of $50 \%$ in spring and a minimum of $11.1 \%$ in summer. Compared with female gametophytes (cystocarpic thalli) $(29.4 \pm 2.9 \%, n=14)$, the tetrasporophytes (tetrasporic thalli) are usually less abundant (24.5 $\pm 3.4 \%, n=14)$; the predominance of gametophytes in C. crispus populations was also found in other works [37-39]. The average percentage of nonfructified thalli was $46.1 \pm 3.9 \%$ $(n=14)$. The data on seasonal variation in the percentage of individuals of each generation have statistical significance (one-way ANOVA, $P<0.001$ ).

G. pistillata is the type of species of the Gigartina genus [40, 41]; despite possessing an isomorphic triphasic lifecycle [42], it shows heterosporic thalli (i.e., producing both tetraspores and carpospores) $[43,44]$, which were found in all studied samples. The tetrasporophytes were dominant in most samples, and the percentage varied from $10 \%$ (spring) to $81.8 \%$ (late autumn). The female gametophytes were present in all samples, varying the proportion of $6.8 \%$ (late autumn) to $90 \%$ (spring). The heterosporic thalli were present in all samples, with a maximum of $30.8 \%$ in early winter and a minimum of $1.9 \%$ in summer. The data on seasonal variation in the percentage of individuals of each generation have statistical significance (one-way ANOVA, $P<0.001$ ).

C. acicularis presents an isomorphic triphasic lifecycle [41], but the nonfructified thalli and the tetrasporophytes are difficult to distinguish from one another, and consequently these reproductive phases were not separated. 


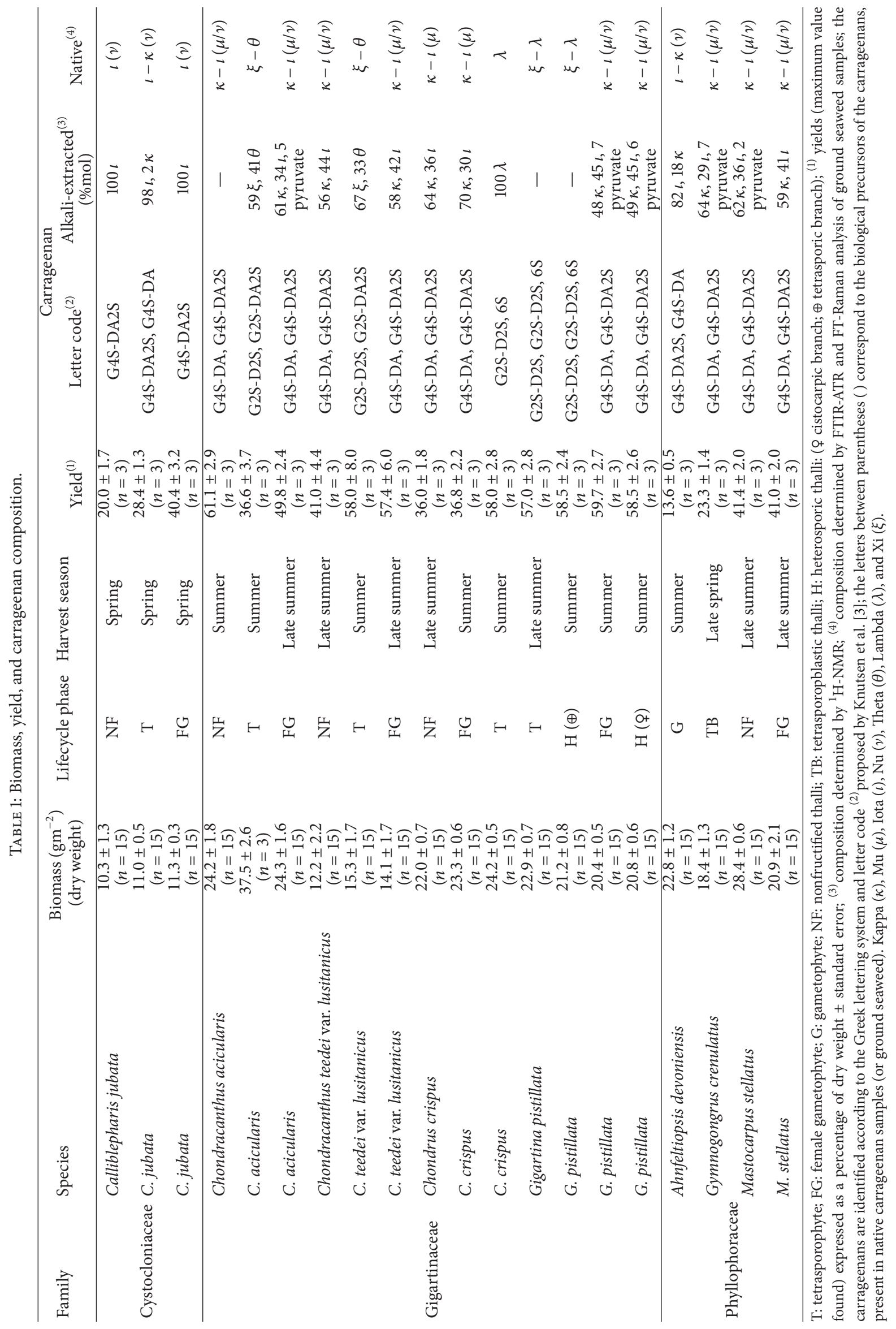




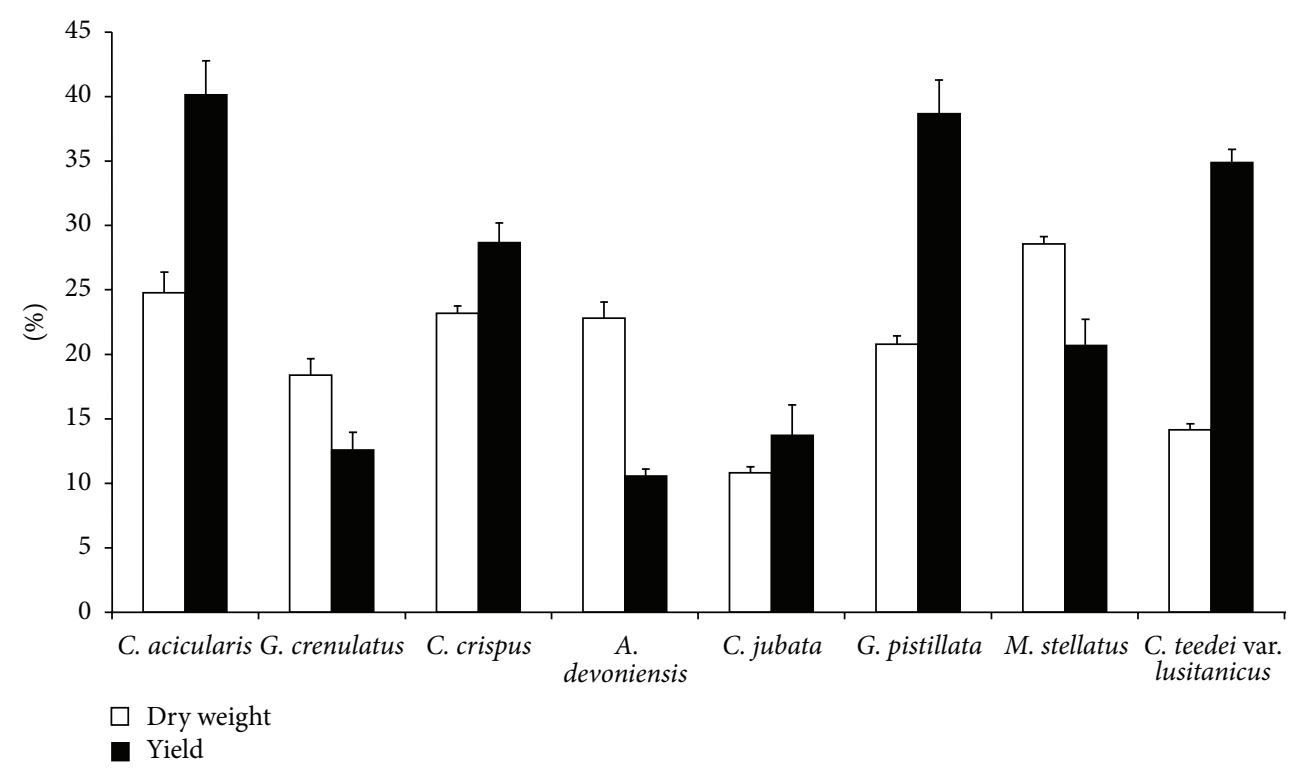

FIGURE 1: Carrageenophytes dry weight expressed as the percentage of fresh weight and carrageenan yields expressed as the percentage of dry weight (average \pm standard error, $n=13$ ).

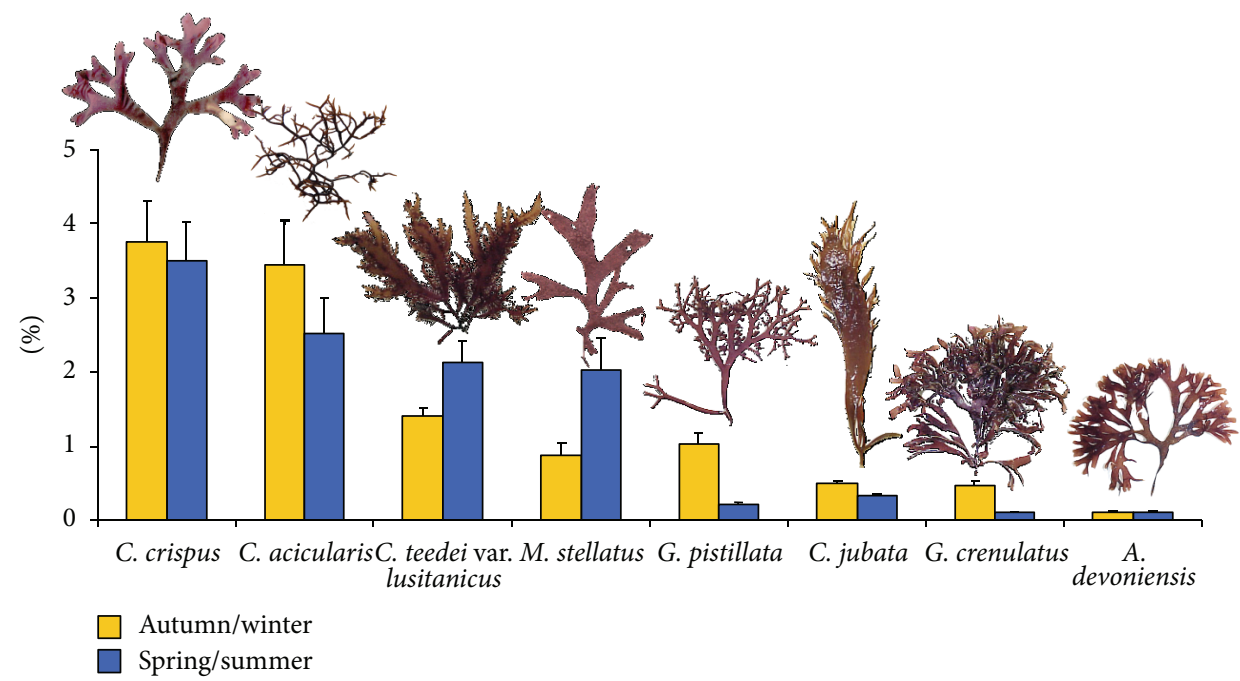

FIGURE 2: Carrageenophytes coverage in autumn/winter and spring/summer (average \pm standard error, $n=46$ ).

M. stellatus presents a heteromorphic triphasic lifecycle with a sporophytic crust, formerly Petrocelis cruenta [45]. Only the gametophytic phase was studied. The studied population presents a predominance of nonfructified plants in winter and a predominance of female gametophytes in spring/summer (Figure 4).

C. teedei var. lusitanicus presents an isomorphic triphasic lifecycle $[31,46]$. In Buarcos bay population, the nonfructified thalli were dominant in all samples (see Figure 5); the percentage varied from $43 \%$ (early autumn) to $82.5 \%$ (early summer). The female gametophytes were present in all samples, varying the proportion of $3 \%$ (late autumn) to $29 \%$ (late summer). The tetrasporophytes were also present in all samples, with a maximum of $32.5 \%$ in autumn and a minimum of $4 \%$ in summer. As compared to fructified thalli, namely, the female gametophytes bearing cystocarps $(9.6 \pm 1.7 \%, n=17)$, the tetrasporophytes are, generally, more abundant $(21 \pm 1.7 \%, n=17)$. The average percentage of nonfructified thalli was $69.4 \pm 2.2 \%(n=17)$. The data on seasonal variation in the percentage of individuals of each generation have statistical significance (one-way ANOVA, $P<0.001)$.

C. jubata shows an isomorphic triphasic lifecycle [47], and the nonfructified plants were dominant in all samples, except in a summer sample (August); the percentage varied from $28.6 \%$ (summer) to $100.0 \%$ (autumn and early winter) (Figure 6). The female gametophytes were present in 11 of 13 samples, varying the proportion of $2.4 \%$ (late winter) 


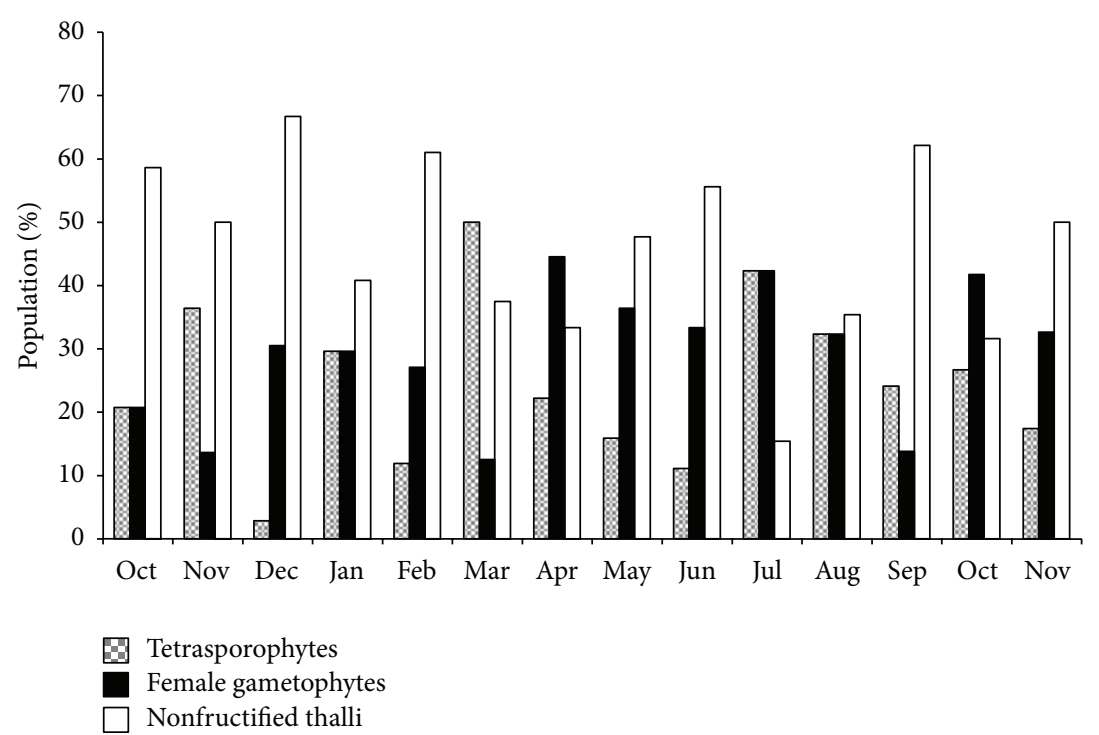

Figure 3: Population structure of Chondrus crispus in Buarcos bay.

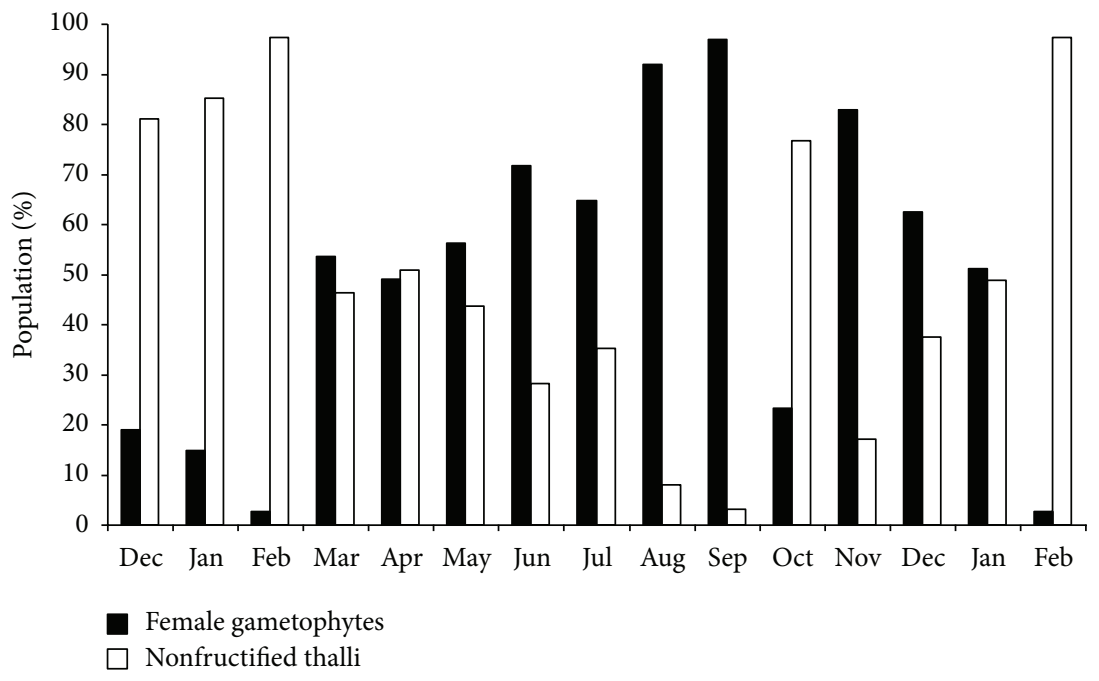

FIgURE 4: Population structure of Mastocarpus stellatus in Buarcos bay.

to $71.4 \%$ (summer). The tetrasporophytes were present in 4 of 13 samples, with a maximum of $17.3 \%$ in spring and a minimum of $5.3 \%$ in winter. Comparing the fructified plants, particularly female gametophytes $(20.3 \pm 5.3 \%, n=$ $13)$, tetrasporophytes are always less abundant $(11.3 \pm 1.5 \%$, $n=13)$. The average percentage of nonfructified thalli was $20.8 \pm 5.6 \%(n=13)$. The data on seasonal variation in the percentage of individuals of each generation have statistical significance (one-way ANOVA, $P<0.001$ ).

The female gametophytes of $G$. crenulatus (species with a digenetic lifecycle) present reproductive structures known as tetrasporoblasts $[46,48,49]$; these structures appear as external wart-like excrescences. All the collected thalli showed tetrasporoblasts. A. devoniensis presents a heteromorphic triphasic lifecycle with crustose tetrasporophytes [46, 50]. Only the gametophytic phase was studied. The cystocarps were present in the gametophytes sampled in December, January, and March.

Our results are similar to those presented in other works on the North Atlantic [17, 37, 38, 49, 51] and the Iberian Peninsula carrageenophytes $[1,21]$.

3.4. Variation in Dry Weight and Carrageenan Content. The dry weight and carrageenan content average values are shown in Figure 1.The maximum carrageenan content in C. crispus (see Table 1) was found in a tretrasporic thalli sample in summer, with $53.2 \%$ of dry weight; a sample of female gametophytes presented the minimum value in late autumn, with $10 \%$ of dry weight. The data on seasonal variation of carrageenan content show statistical significance (one-way ANOVA, $P<0.01)$. 


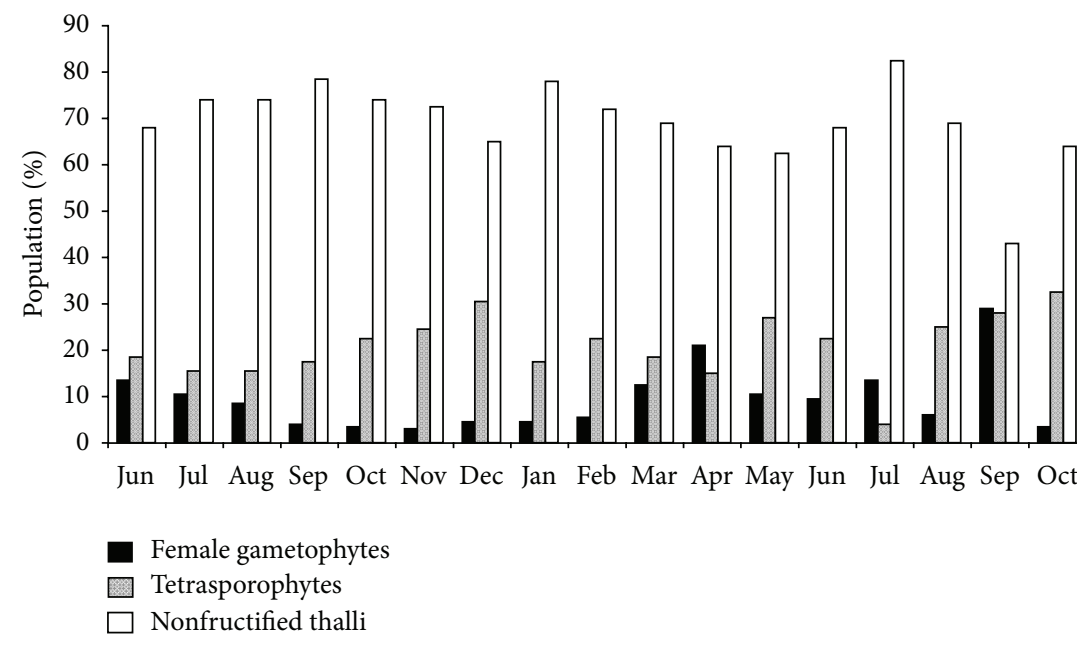

Figure 5: Population structure of Chondracanthus teedei var. lusitanicus in Buarcos bay.

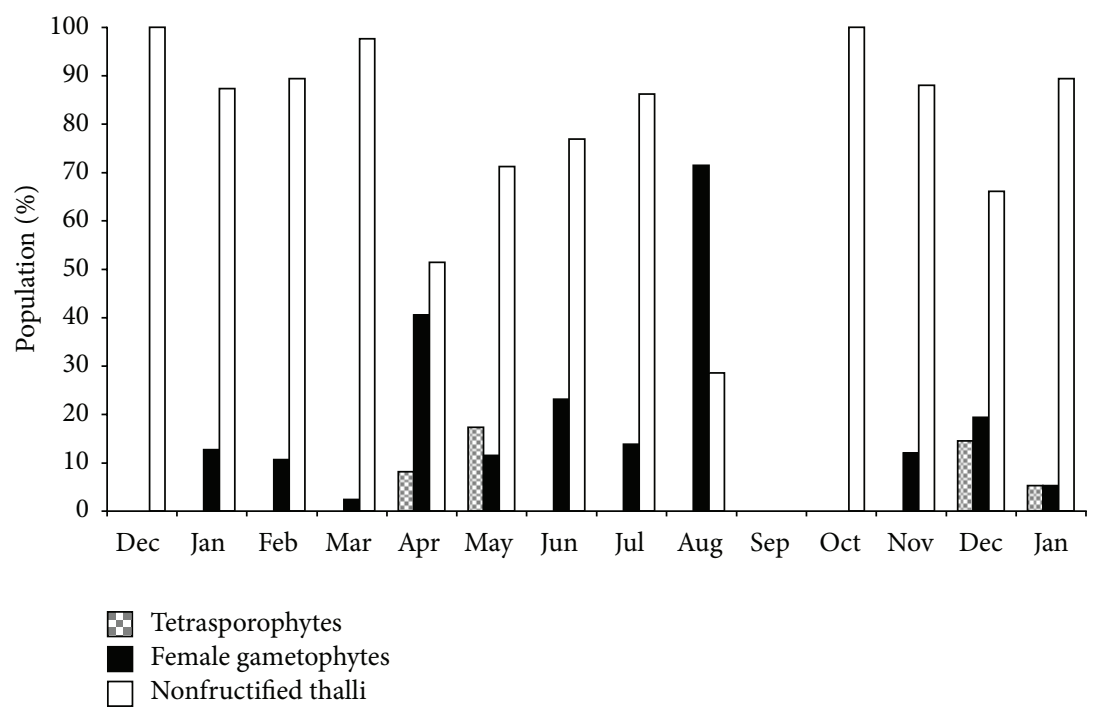

FIgURE 6: Population structure of Calliblepharis jubata in Buarcos bay.

The maximum carrageenan content in G. pistillata (Table 1) was found in a sample of female gametophytes, with $59.7 \%$ of dry weight in late spring; a sample of heterosporic thalli presented the minimum value in late autumn, with $22.7 \%$ of dry weight. The data on seasonal variation of carrageenan content show statistical significance (one-way ANOVA, $P<0.001$ ).

The population of $M$. stellatus is composed of about $50 \%$ of female gametophytes and $50 \%$ of nonfructified thalli, both showing a similar maximum carrageenan content (see Table 1) in summer, with about $41 \%$ dry weight. However, the average carrageenan content $(20.7 \pm 2.0 \%, n=14)$ is relatively low, when compared to other carrageenophytes from Buarcos bay (Figure 1). The data on seasonal variation of carrageenan content show statistical significance (one-way ANOVA, $P<$ 0.001).

Dry matter in C. teedei var. lusitanicus (Figure 1) varied between $12.1 \pm 1.5 \%(n=3)$ in late autumn and
$17.5 \pm 0.8 \%(n=3)$ in winter. The maximum carrageenan content $(58 \%)$ was found in a tetrasporophyte sample collected in summer (Table 1) and the minimum content was found in a nonfructified sample, with $23 \%$ in winter. The overall phycocolloid content was minimum $(26.4 \pm 2.5 \%, n=3)$ in winter and maximum $(43.6 \pm 12.5 \%, n=3)$ in early summer. The data on seasonal variation of dry weight and carrageenan content have statistical significance (one-way ANOVA, $P<$ 0.001 and $P<0.05$, resp.).

The average dry weight in C. acicularis ranged from $18.3 \pm$ $0.2 \%(n=3)$ in late spring to $33.0 \pm 2.7 \%(n=3)$ in autumn. The average dry weight was $24.8 \pm 2.7(n=13)$. The maximum carrageenan content $(61.1 \%)$ was found in a nonfructified thalli sample collected in summer (Table 1), and the minimum content was found in a female gametophyte sample, with $21.7 \%$ in autumn. The overall phycocolloid content was minimum $(29.4 \pm 4.3 \%, n=3)$ in autumn and maximum $(55.5 \pm 4.6 \%, n=3)$ in summer. The data on 
seasonal variation of dry weight and carrageenan content have statistical significance (one-way ANOVA, $P<0.001$ ).

All the three remaining species, C. jubata, G. crenulatus, and $A$. devoniensis, are producers of iota-carrageenan and have been studied in other countries $[49,51,52]$. In general, our results are in accordance with those studies. The carrageenan content of these species is relatively low, varied from $10.1 \%$ in $A$. devoniensis to $13 \%$ in C. jubata, passing by $12.4 \%$ in G. crenulatus. Furthermore, the cover (Figure 2) and biomass are very low.

3.5. Carrageenan Composition. The ground seaweed samples FTIR-ATR spectra (not shown) of C. crispus, M. stellatus, and $G$. pistillata (female gametophytes) and the nonfructified plants of C. crispus exhibit strong absorption bands in the region of $930 \mathrm{~cm}^{-1}$ (DA) and the region of $845 \mathrm{~cm}^{-1}$ (G4S), typical of the kappa-carrageenan. These spectra have low absorbance in the region $805 \mathrm{~cm}^{-1}$ (DA2S), which means the presence of iota-carrageenan [8]. Female gametophytes of $C$. crispus, M. stellatus, and G. pistillata and the nonfructified plants of C. crispus ground seaweed FT-Raman spectra show two bands in the region $807 \mathrm{~cm}^{-1}$ (DA2s) and $850 \mathrm{~cm}^{-1}$ (G4S), typical of kappa/iota-hybrid carrageenans. The occurrence of additional peaks $821 \mathrm{~cm}^{-1}$ (G/D6S), $830 \mathrm{~cm}^{-1}$ (G/D2S), and $870 \mathrm{~cm}^{-1}$ (G/D6S) shows the presence of muand nu-carrageenan and biological precursors of kappa- and iota-carrageenan, respectively [8]. Our results agree with those obtained in other studies conducted with $C$. crispus [7, 53-55], M. stellatus [7, 56, 57], and G. pistillata [58-60].

In female gametophytes and nonfructified thalli of $C$. teedei var. lusitanicus, the FTIR-ATR spectra show strong absorption at 930 (DA) and $845 \mathrm{~cm}^{-1}$ (G4S) and median absorption in the band $805 \mathrm{~cm}^{-1}$ (DA2S). Additional peaks at $867 \mathrm{~cm}^{-1}$ (G/D6S), $825 \mathrm{~cm}^{-1}$ (G/D2S), and $820 \mathrm{~cm}^{-1}$ (G/D6S), with little intensity, correspond to the presence of carrageenan precursors ( $\mathrm{mu}$ and $\mathrm{nu}$ ). The presence of bands at $820 \mathrm{~cm}^{-1}, 825 \mathrm{~cm}^{-1}$, and $867 \mathrm{~cm}^{-1}$, corresponding to the existence of precursors, is more evident in the FT-Raman spectra. These results agree with those obtained in other studies conducted with $C$. teedei $[7,8,31,61]$.

For the species A. devoniensis, G. crenulatus, and $C$. jubata, the FTIR-ATR spectra show absorption bands at 930, 845 , and $805 \mathrm{~cm}^{-1}$, which represent the characteristic triplet of the fraction iota, when dominant in a hybrid carrageenan. The FT-Raman spectra of $A$. devoniensis and $G$. crenulatus show two bands in the region $807 \mathrm{~cm}^{-1}$ (DA2S) and $850 \mathrm{~cm}^{-1}$ (G4S), typical of hybrid kappa/iota carrageenans. The peaks related to the carrageenan precursors, $\mathrm{mu}$ and nu, are $821 \mathrm{~cm}^{-1}$ (G/D6S), $830 \mathrm{~cm}^{-1}$ (G/D2S), and $870 \mathrm{~cm}^{-1}$ (G/D6S) [8].

The intensity of the resonances in ${ }^{1} \mathrm{H}$-NMR spectra $[14$, 34] was used in this work in order to quantify the different carrageenan fractions (see Table 1). The alkali-extracted carrageenans showed lower sulphate content and a decrease in galactose to the benefit of 3,6-anhydrogalactose. This corresponds to the conversion of the 4-linked galactose-6sulfate in native samples to anhydrogalactose in the alkaliextracted carrageenans. Thus, the carrageenan precursor's mu and nu were converted into kappa- and iota-carrageenan, respectively [31].

\section{Conclusion}

Several investigators $[49,51,52,54,58]$ have described seasonal fluctuations of carrageenan quantity and compositions in some Gigartinales. In this study, most of the seaweeds present high carrageenan contents in summer (C. crispus, C. teedei var. lusitanicus, G. pistillata, C. jubata, and G. crenulatus); however, the maximum carrageenan content in $C$. acicularis and $A$. devoniensis is found in autumn/winter.

In C. crispus, the carrageenan content was low in autumn and winter, a small increase occurred in early spring (April), and the largest carrageenan content was recorded in samples collected in summer (July). In G. pistillata, the carrageenan content was low in autumn and winter, a large increase occurred in early spring (March), and the biggest carrageenan content was recorded in samples collected in spring (June) and summer (July and August). In C. acicularis, carrageenan content was low in autumn and winter, a small increase occurred in early spring (March), and the highest carrageenan content was recorded in samples collected in summer (July). In M. stellatus, the carrageenan content was low in winter and spring, a small increase occurred in early summer (June), and the highest carrageenan content was recorded in samples collected at the end of summer (September). In $A$. devoniensis, the carrageenan content was low throughout the study period and a small increase occurred only in summer (June). In G. crenulatus, the carrageenan content was low during the autumn, and a small increase occurred in winter; the spring samples and in particular those of summer have a higher carrageenan content. Finally, in C. jubata the yield was low in autumn and winter; the highest carrageenan content was recorded in samples collected in spring (May).

So, by the combination of high biomass and carrageenan content available in summer, we can conclude that this is the best period to harvest the Portuguese dominant carrageenophytes, with the exception of $C$. acicularis, that will have to be harvested in autumn/winter. Other studies carried out in North Atlantic coasts showed an increase in carrageenan content during summer and a decrease in winter, namely, in C. crispus [54], C. jubata [51, 52], and G. crenulatus [49].

In relation to the nature of the phycocolloid, our vibrational and resonance spectroscopic analysis showed that the Portuguese carrageenophytes studied seem to present a similar composition to that found in other species of Cystocloniaceae, Gigartinaceae, and Phyllophoraceae families [5].

In conclusion, some species found in the central north coast of Iberian Peninsula could be used for industrial applications. Kappa, kappa-iota hybrid, and lambda fractions can be provided by harvesting C. crispus, M. stellatus, $C$. teedei var. lusitanicus, and C. acicularis. However, responsible harvesting of natural populations must be always the norm, because the nonsustainable procedures can have severe economic and environmental impacts. On the other hand and due to its limited stock in the western coast, G. pistillata (source of hybrid kappa-iota and xi-lambda carrageenans), 
C. jubata, G. crenulatus, and A. devoniensis (sources of iotacarrageenan) should be, in future, objects of culture essays in order to research their potentialities in biomass production.

\section{Acknowledgments}

The author acknowledges the financial support of the Portuguese Foundation for Science and Technology (FCT) and the Institute of Marine Research (IMAR-CMA).

\section{References}

[1] L. Pereira and F. van de Velde, "Portuguese carrageenophytes: carrageenan composition and geographic distribution of eight species (Gigartinales, Rhodophyta)," Carbohydrate Polymers, vol. 84, no. 1, pp. 614-623, 2011.

[2] F. van de Velde and G. A. de Ruiter, "Carrageenan," in Biopolymers, A. Steinbüchel, S. de Baets, and E. J. VanDamme, Eds., vol. 6 of Polysaccharides II: Polysaccharides from Eukaryotes, pp. 245-274, Wiley-VCH, Weinheim, Germany, 2002.

[3] S. H. Knutsen, D. E. Myslabodski, B. Larsen, and A. I. Usov, "A modified system of nomenclature for red algal galactans," Botanica Marina, vol. 37, no. 2, pp. 163-169, 1994.

[4] J. S. Craigie, "Cell walls," in Biology of the Red Algae, K. M. Cole and R. G. Sheath, Eds., pp. 221-257, Cambridge University Press, Cambridge, UK, 1990.

[5] T. Chopin, B. F. Kerin, and R. Mazerolle, "Phycocolloid chemistry as a taxonomic indicator of phylogeny in the Gigartinales, Rhodophyceae: a review and current developments using Fourier transform infrared diffuse reflectance spectroscopy," Phycological Research, vol. 47, no. 3, pp. 167-188, 1999.

[6] B. Rudolph, "Seaweed products: red algae of economic significance," in MarIne \& Freshwater Products Handbook, R. E. Martin, Ed., pp. 515-529, Technomic, Lancaster, UK, 2000.

[7] L. Pereira and J. F. Mesquita, "Carrageenophytes of occidental Portuguese coast: 1-spectroscopic analysis in eight carrageenophytes from Buarcos bay," Biomolecular Engineering, vol. 20, no. 4-6, pp. 217-222, 2003.

[8] L. Pereira, A. M. Amado, A. T. Critchley, F. van de Velde, and P. J. A. Ribeiro-Claro, "Identification of selected seaweed polysaccharides (phycocolloids) by vibrational spectroscopy (FTIR-ATR and FT-Raman)," Food Hydrocolloids, vol. 23, no. 7, pp. 1903-1909, 2009.

[9] L. Pereira, A. T. Critchley, A. M. Amado, and P. J. A. RibeiroClaro, "A comparative analysis of phycocolloids produced by underutilized versus industrially utilized carrageenophytes (Gigartinales, Rhodophyta)," Journal of Applied Phycology, vol. 21, no. 5, pp. 599-605, 2009.

[10] H. J. Bixler, K. Johndro, and R. Falshaw, "Structure and performance of commercial extracts II. Performance in two simulated dairy applications," Food Hydrocolloids, vol. 15, no. 4-6, pp. 619630, 2001.

[11] K. F. Wong and J. S. Craigie, "Sulfohydrolase activity and carrageenan biosynthesis in Chondrus crispus (Rhodophyceae)," Plant Physiology, vol. 61, pp. 663-666, 1978.

[12] G. A. de Ruiter, O. Richard, B. Rudolph et al., "Sulfohydrolases, corresponding amino acid and nucleotide sequences, sulfohydrolase preparations, processes, and products thereof," World patent application, WO0068395, 2000.
[13] J. T. Aguilan, J. E. Broom, J. A. Hemmingson et al., "Structural analysis of carrageenan from farmed varieties of Philippine seaweed," Botanica Marina, vol. 46, no. 2, pp. 179-192, 2003.

[14] F. van de Velde, S. H. Knutsen, A. I. Usov, H. S. Rollema, and A. S. Cerezo, "1 $\mathrm{H}$ and ${ }^{13} \mathrm{C}$ high resolution NMR spectroscopy of carrageenans: application in research and industry," Trends in Food Science and Technology, vol. 13, no. 3, pp. 73-92, 2002.

[15] L. Pereira, "A review of the nutrient composition of selected edible seaweeds," in Seaweed: Ecology, Nutrient Composition and MedicInal Uses, V. H. Pomin, Ed., pp. 15-47, Nova Science, New York, NY, USA, 2011.

[16] X. Briand, "Seaweed harvesting in Europe," in Seaweed, Resources In Europe-Uses and Potential, M. D. Guiry and G. Blunden, Eds., pp. 259-308, John Wiley \& Sons, Toronto, Canada, 1991.

[17] R. Perez, R. Kaas, F. Campello, S. Arbault, and O. Barbaroux, La Culture des Algues Marines Dans le Monde, Institut Française de Recherche pour L'Explotation de la Mer, Centre de Brest, IFREMER, Plouzane, France, 1992.

[18] F. P. Palminha, "Exploração e utilização de algas marinhas na plataforma portuguesa e nas ilhas do Arquipélago dos Açores," Junta Nacional de Fomento das Pescas, no. 7, pp. 25-36, 1971.

[19] I. Sousa-Pinto and R. Araújo, "The seaweed resources of Portugal," in World Seaweed Resources: An Authoritative Reference System, A. Critchley, M. Ohno, and D. Largo, Eds., ETI Information Services, Berkshire, UK, 2006.

[20] R. Santos and P. Duarte, "Marine plant harvest in Portugal," Journal of Applied Phycology, vol. 3, no. 1, pp. 11-18, 1991.

[21] M. García Tasende, M. Cid, and M. I. Fraga, "Spatial and temporal variations of Chondrus crispus (Gigartinaceae, Rhodophyta) carrageenan content in natural populations from Galicia (NW Spain)," Journal of Applied Phycology, vol. 24, no. 4, pp. 941-951, 2012.

[22] M. G. Tasende, M. Cid, and M. I. Fraga, "Qualitative and quantitative analysis of carrageenan content in gametophytes of Mastocarpus stellatus (Stackhouse) Guiry along Galician coast (NW Spain)," Journal of Applied Phycology, vol. 25, no. 2, pp. 587-596, 2013.

[23] D. J. McHugh, "A guide to the seaweed industry," Tech. Rep. 441, FAO, 2003.

[24] H. J. Bixler and H. Porse, "A decade of change in the seaweed hydrocolloids industry," Journal of Applied Phycology, vol. 23, no. 3, pp. 321-335, 2011.

[25] L. Pereira, "Identification of phycocolloids by vibrational spectroscopy," in World Seaweed Resources-An Authoritative Reference System, A. T. Critchley, M. Ohno, and D. B. Largo, Eds., vol. 1.0 of Hybrid Windows and Mac, ETI Information Services, 2006.

[26] L. Pereira, F. S. Gheda, and P. J. A. Ribeiro-Claro, "Analysis by vibrational spectroscopy of seaweed polysaccharides with potential use in food, pharmaceutical and cosmetic industries," International Journal of Carbohydrate Chemistry, vol. 2013, Article ID 537202, 7 pages, 2013.

[27] D. Krause-Jensen, J. Carstensen, and K. Dahl, "Total and opportunistic algal cover in relation to environmental variables," Marine Pollution Bulletin, vol. 55, no. 1-6, pp. 114-125, 2007.

[28] J. M. Neto, R. Gaspar, L. Pereira, and J. C. Marques, "Marine Macroalgae Assessment Tool (MarMAT) for intertidal rocky shores. Quality assessment under the scope of the European Water Framework Directive," Ecological Indicators, vol. 19, pp. 39-47, 2012. 
[29] M. R. A. Braga, "Reproductive characteristics of Gigartina teedii (Roth) Lamouroux (Rhodophyta, Gigartinales), a turf-forming species-field and laboratory culture studies," Botanica Marina, vol. 33, no. 5, pp. 401-409, 1990.

[30] T. Chopin, "Marine Biodiversity Monitoring: protocol for monitoring of seaweeds," A report by the Marine Biodiversity Monitoring Committee (Atlantic Maritime ecological science Co-operative, Huntsman Marine Science Center) to the Ecological Monitoring and Assessment Network of Environment Canada, 2000, http://macoi.ci.uc.pt/include/downloadContentDoc.php?id=12.

[31] L. Pereira and J. F. Mesquita, "Population studies and carrageenan properties of Chondracanthus teedei var. lusitanicus (Gigartinaceae, Rhodophyta)," Journal of Applied Phycology, vol. 16, no. 5, pp. 369-383, 2004.

[32] L. Pereira, A. Sousa, H. Coelho, A. M. Amado, and P. J. A. Ribeiro-Claro, "Use of FTIR, FT-Raman and 13C-NMR spectroscopy for identification of some seaweed phycocolloids," Biomolecular Engineering, vol. 20, no. 4-6, pp. 223-228, 2003.

[33] J. H. Zar, Biostatistical Analysis, Prentice Hall International, London, UK, 1996.

[34] F. van de Velde, L. Pereira, and H. S. Rollema, “The revised NMR chemical shift data of carrageenans," Carbohydrate Research, vol. 339, no. 13, pp. 2309-2313, 2004.

[35] L. C. M. Chen and J. McLachlan, "The life history of Chondrus crispus in culture," Canadian Journal of Botany, vol. 50, pp. 10551060, 1971.

[36] M. D. Guiry, "Chondrus crispus Stackhouse "T4" is a male clone (Rhodophyta)," Phycologia, vol. 20, no. 4, pp. 439-449, 1981.

[37] M. T. Brown, A. Neish, and D. Harwood, "Comparison of three techniques for identifying isomorphic phases of Chondrus crispus (Gigartinaceae)," Journal of Applied Phycology, vol. 16, no. 6, pp. 447-450, 2004.

[38] R. Scrosati and B. Mudge, "Persistence of gametophyte predominance in Chondrus crispus (Rhodophyta, Gigartinaceae) from Nova Scotia after 12 years," Hydrobiologia, vol. 519, no. 1-3, pp. 215-218, 2004.

[39] R. Scrosati, D. J. Garbary, and J. McLachlan, "Reproductive ecology of Chondrus crispus (Rhodophyta, Gigartinales) from Nova Scotia, Canada," Botanica Marina, vol. 37, no. 4, pp. 293300, 1994.

[40] D. H. Kim, "A study of the development of cystocarps and tetrasporangial sori in Gigartinaceae (Rhodophyceae, Gigartinales)," Nova Hedwigia, vol. 27, pp. 1-146, 1976.

[41] M. H. Hommersand, M. D. Guiry, S. Fredericq, and G. L. Leister, "New perspectives in the taxonomy of the Gigartinaceae (Gigartinales, Rhodophyta)," Hydrobiologia, vol. 260-261, no. 1, pp. 105-120, 1993.

[42] M. Hommersand, S. Fredericq, and J. Cabioch, "Developmental morphology of Gigartina pistillata (Gigartinaceae, Rhodophyta)," Phycologia, vol. 31, pp. 300-325, 1992.

[43] W. E. Isaac and S. M. Simons, "Some observations on Gigartina pistillata (Gmel.) Stackh. from Port Alfred with a record of plants bearing both tetraspores and carpospores," Journal of South African Botany, vol. 20, pp. 117-125, 1954.

[44] L. Pereira, J. F. Mesquita, and J. D. S. Dias, "Optical and electron microscope study of heterosporic thalli (carpospores/tetraspores) in Gigartina pistillata (Gmel.) Stackh. (Rhodophyta)," in Proceedings of the 15th International Congress on Electron Microscopy (ICEM '02), vol. 2 of Biology and Medicine, pp. 747-748, Durban, South Africa, 2002.
[45] M. D. Guiry, J. A. West, D. H. Kim, and M. Masuda, "Reinstatement of the Genus Mastocarpus Kutzing (Rhodophyta)," Taxon, vol. 33, pp. 53-63, 1984.

[46] L. Pereira, "Cytological and cytochemical aspects in selected carrageenophytes (Gigartinales, Rhodophyta)," in Advances in Algal Cell Biology, K. Heimann and C. Katsaros, Eds., pp. 81104, Walter De Gruyter, Berlin, Germany, 2012.

[47] P. S. Dixon and L. M. Irvine, Seaweeds of the British Isles, Vol. I-Rhodophyta, Part 1-Introduction, Nemaliales, Gigartinales, The Natural History Museum, B. P. Society, London, UK, 1995.

[48] P. Gayral, "Les Algues de côtes françaises (manche et atlantique), notions fondamentales sur l'écologie, la biologie et la systématique des algues marines," Tech. Rep., Deren et Cie, Paris, France, 1966.

[49] A. C. Mathieson, C. Emerich Penniman, and E. TveterGallagher, "Phycocolloid ecology of underutilized economic red algae," Hydrobiologia, vol. 116-117, no. 1, pp. 542-546, 1984.

[50] C. A. Maggs, S. E. Douglas, J. Fenety, and C. J. Bird, "A molecular and morphological analysis of the Gymnogongrus devoniensis (Rhodophyta) complex in the North Atlantic," Journal of Phycology, vol. 28, pp. 241-232, 1992.

[51] J. Cosson, E. Deslandes, and J. P. Braud, "Preliminary approach to the characterization and seasonal variation of carrageenans from four Rhodophyceae on the Normandy coast (France)," Hydrobiologia, vol. 204-205, no. 1, pp. 539-544, 1990.

[52] M. Zinoun and J. Cosson, "Seasonal variation in growth and carrageenan content of Calliblepharis jubata (Rhodophyceae, Gigartinales) from the Normandy coast, France," Journal of Applied Phycology, vol. 8, no. 1, pp. 29-34, 1996.

[53] J. Kopp, Contribuition à l'étude de l'algue rouge Chondrus crispus Stackh. Biochimie des carraghénanes [Ph.D. thesis], Université Bretagne Occidentale, 1978.

[54] J. Kopp and J. Perez, "Contribuition à l'étude de l'álgue rouge Chondrus crispus Stackh. Relation entre la croissance, la potentialité sexuelle, la quantité e la composition de carraghénanes," Revue des Travaux de l'Institut des Peches Maritimes, vol. 42, pp. 291-324, 1979.

[55] T. Chopin and J.-Y. Floch, "Eco-physiological and biochemical study of two of the most contrasting forms of Chondrus crispus (Rhodophyta, Gigartinales)," Marine Ecology Progress Series, vol. 81, no. 2, pp. 185-195, 1992.

[56] L. Hilliou, F. D. S. Larotonda, A. M. Sereno, and M. P. Gonçalves, "Thermal and viscoelastic properties of $\kappa / \iota$-hybrid carrageenan gels obtained from the Portuguese seaweed Mastocarpus stellatus," Journal of Agricultural and Food Chemistry, vol. 54, no. 20, pp. 7870-7878, 2006.

[57] L. Hilliou, F. D. S. Larotonda, P. Abreu, A. M. Ramos, A. M. Sereno, and M. P. Gonçalves, "Effect of extraction parameters on the chemical structure and gel properties of $\kappa / l$-hybrid carrageenans obtained from Mastocarpus stellatus," Biomolecular Engineering, vol. 23, no. 4, pp. 201-208, 2006.

[58] A. Amimi, A. Mouradi, L. Bennasser, and T. Givernaud, "Seasonal variations in thalli and carrageenan composition of Gigartina pistillata (Gmelin) Stackhouse (Rhodophyta, Gigartinales) harvested along the Atlantic coast of Morocco," Phycological Research, vol. 55, no. 2, pp. 143-149, 2007.

[59] A. Amimi, A. Mouradi, T. Givernaud, N. Chiadmi, and M. Lahaye, "Structural analysis of Gigartina pistillata carrageenans (Gigartinaceae, Rhodophyta)," Carbohydrate Research, vol. 333, no. 4, pp. 271-279, 2001. 
[60] L. Pereira and J. F. Mesquita, "Cytochemical studies on Portuguese carrageenophytes (Gigartinales, Rhodophyta)," in Proceedings of the 3rd WSEAS International Conference on Cellular and Molecular Biology, Biophysics and Bioengineering, C. A. Long and P. Anninos, Eds., pp. 66-71, World Scientific and Engineering Academy and Society, Athens, Greece, 2007.

[61] M. Zinoun, J. Cosson, and E. Deslandes, "Influence of culture conditions on growth and physicochemical properties of carrageenans in Gigartina teedii (Rhodophyceae, Gigartinales)," Botanica Marina, vol. 36, pp. 131-136, 1993. 

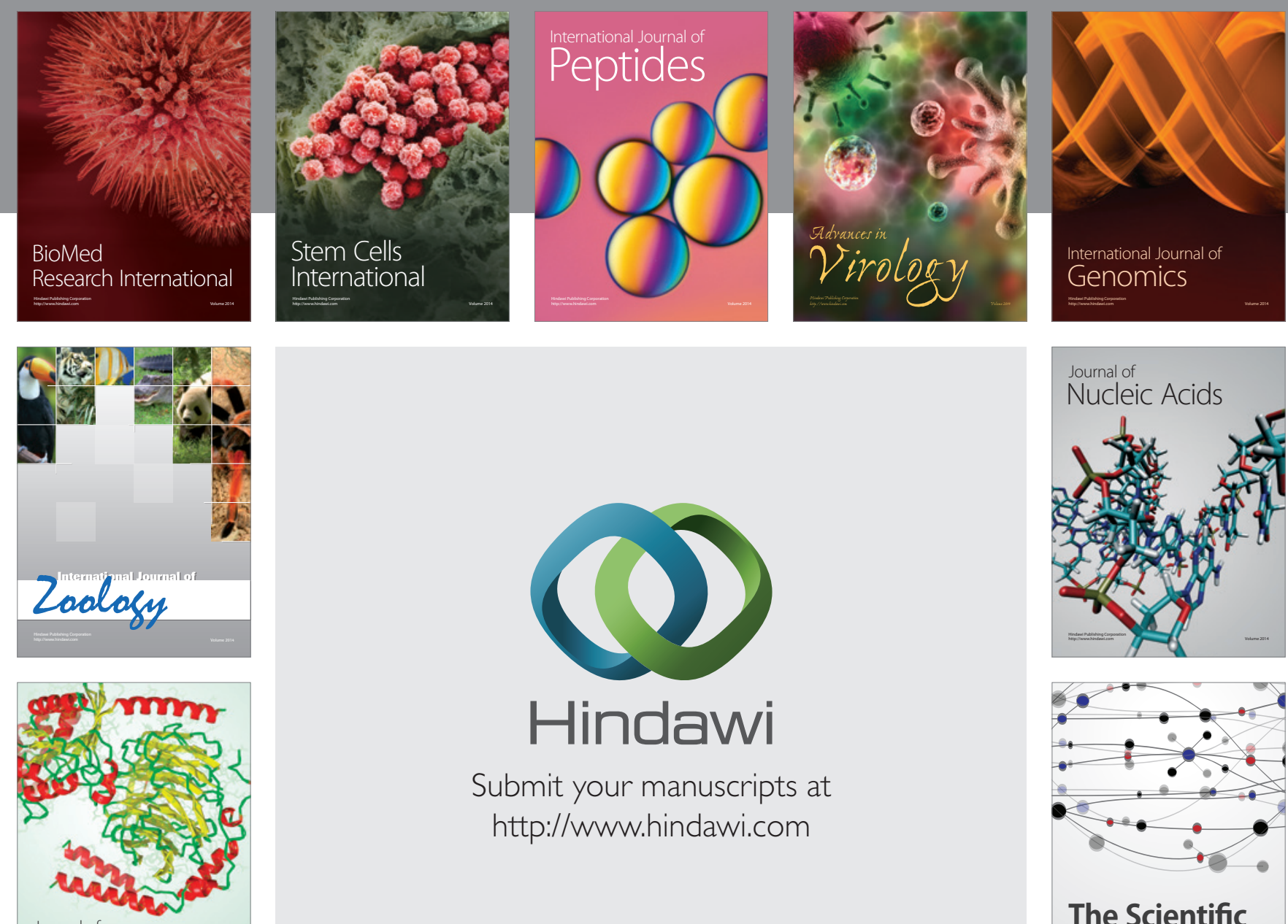

Submit your manuscripts at

http://www.hindawi.com

Journal of
Signal Transduction
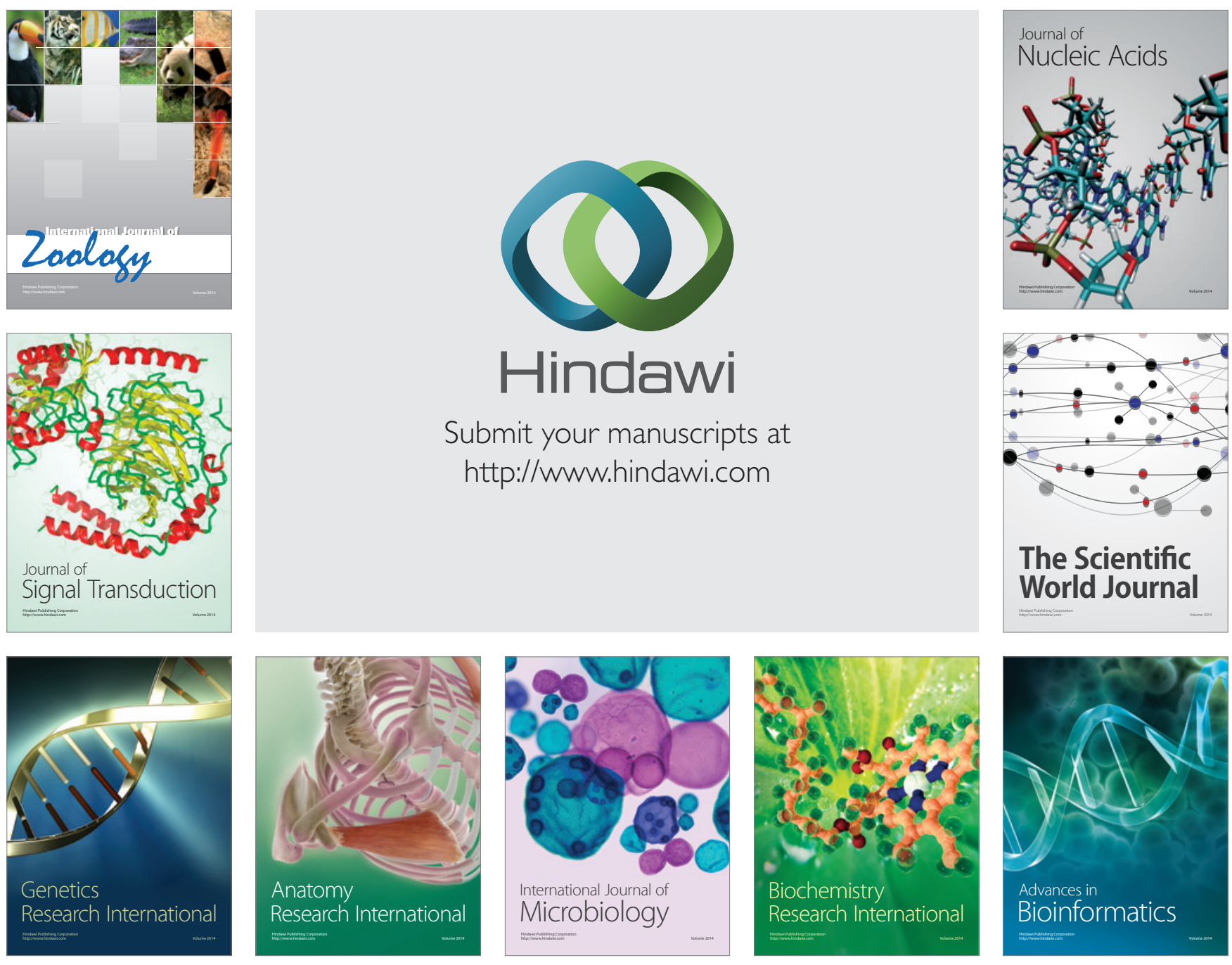

The Scientific World Journal
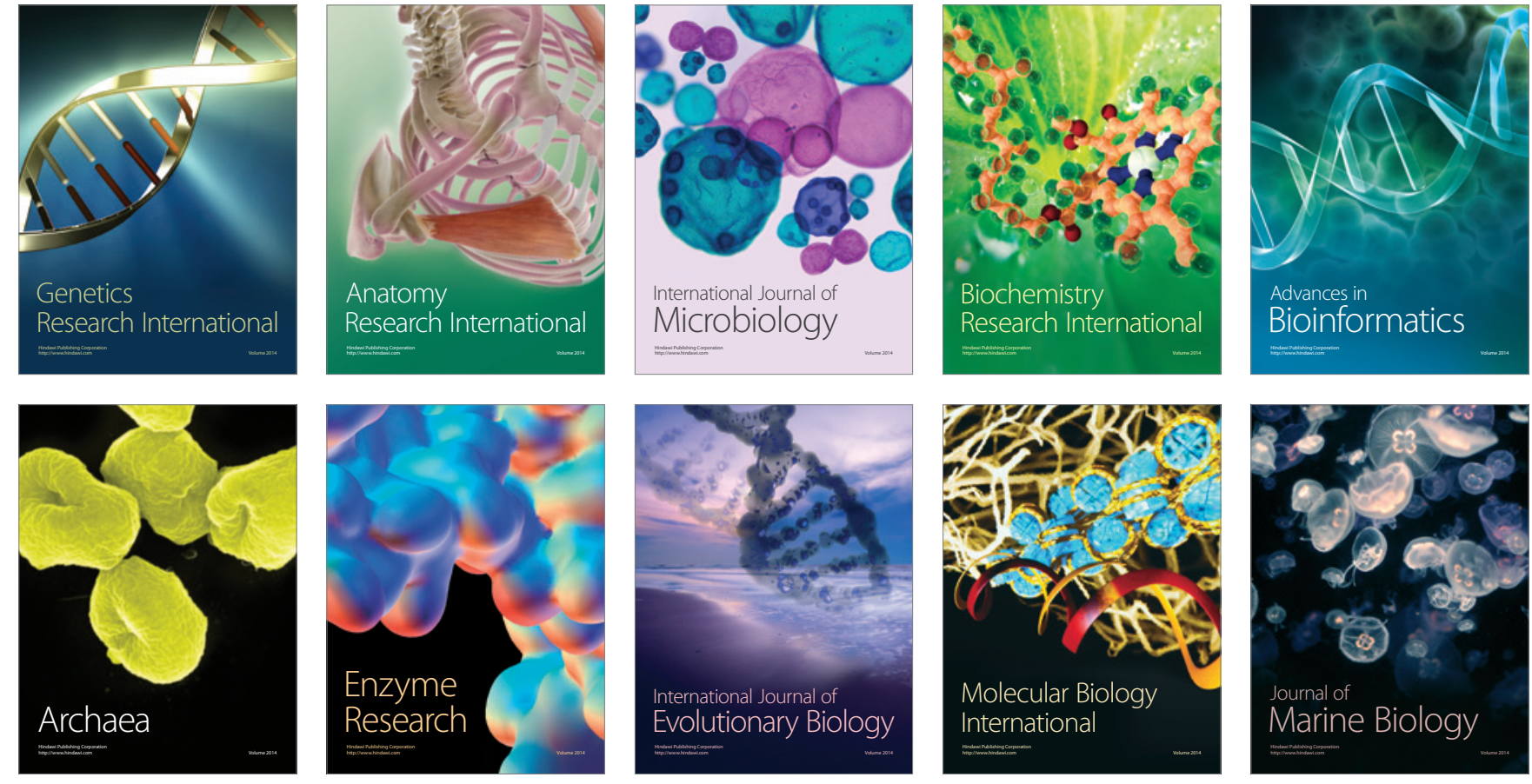